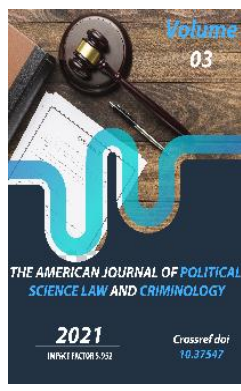

\title{
Independence And Foreign Policy Of The New Uzbekistan: The Results Of Initiatives And Practical Work
}

\author{
Abira Amanovna Huseynova \\ Professor Of Bukhara State University, Member Of The Senate Of The Oliy Majlis Of The \\ Republic Of Uzbekistan
}

Journal Website: https://theamericanjou rnals.com/index.php/ta jpslc

Copyright: Original content from this work may be used under the terms of the creative commons attributes 4.0 licence.

\section{ABSTRACT}

The article analyzes the main directions of the foreign policy of the Republic of Uzbekistan. It also focuses on the measures taken during the years of independence to ensure regional security, take a worthy place in the world community, protect human rights. The content of the initiatives put forward by our country to achieve sustainable development in the new Uzbekistan is revealed.

\section{KEYWORDS}

Foreign policy, independence, security, international cooperation, sustainable development, peace policy, new Uzbekistan.

\section{INTRODUCTION}

It is known that Uzbekistan is one of the youngest countries in the world to gain independence out of about 200 countries. But it has a history of more than 300 years in terms of the formation and establishment of statehood. On August 31, 1991, at the sixth special session of the Supreme Soviet of the Republic, the state independence of Uzbekistan was declared. From the first years of independence, the Republic of Uzbekistan has been striving to take a worthy place in the world community and pursuing its foreign policy relations with many countries in the political, economic and cultural spheres. In the first days of independence, the adoption of the Law "On the Foundations of State Independence of the Republic of Uzbekistan" [6] laid a solid foundation for the independent implementation of Uzbekistan's foreign policy. In this regard, the first President Islam Karimov said: "The fact that Uzbekistan has gained state independence and is internationally 
recognized means that from now on the Republic will pursue an independent domestic and foreign policy, establish mutually beneficial relations without anyone's mediation. It is really in the national interest of the republic ... to raise it in practice".

\section{MATERIALS AND METHODS}

The Republic of Uzbekistan became a full member of the United Nations on March 2, 1992. On October 24, 1993, the UN Office in Uzbekistan was opened in Tashkent, and the Office of Uzbekistan was opened at the UN Headquarters (New York). The principles of the foreign policy of our country are enshrined in Article 17 of the Constitution of the Republic of Uzbekistan [4] and the Law "On the basic principles of the foreign policy of the Republic of Uzbekistan" [5,19].

According to the Constitution, the foreign policy of the Republic of Uzbekistan is based on the sovereign equality of states, non-use of force and threat of force, inviolability of borders, peaceful settlement of disputes through negotiations, non-interference in the internal affairs of other countries and membership in other interstate structures of international law. its highest interests may arise from such alliances and structures due to its well-being and security.

Naturally, the Republic of Uzbekistan conducts its foreign policy based on these universally recognized norms and principles of international law.

Over the past 30 years, Uzbekistan has launched several initiatives for peace, stability and equal cooperation between the state, people and nations in the world since the early years of independence. Effective work is being done for its practical result. Such activity is unique to a country that, with its intellectual potential, becomes a model for states, peoples and nations.

The first attempt. On September 28, 1993, at the 48th session of the UN General Assembly [7], the first President of the Republic of Uzbekistan initiated the transformation of Central Asia into a nuclear-weapon-free zone. Until that time, nuclear-weapon-free zones existed in Southeast Asia, Latin America, Africa, and the Pacific. On September 8, 2006, the UN signed a separate document on this agreement. On March 21, 2009, the Treaty on the Non-Proliferation of Nuclear Weapons in Central Asia entered into force.

The second attempt. At the initiative of Uzbekistan, the "6 + 2" dialogue group was established in 1997 to resolve internal conflicts in Afghanistan. The group, which includes leaders from Uzbekistan, Tajikistan, Turkmenistan, Iran, Pakistan, China, the United States and Russia, operated from 1997 to 2001.

The third attempt. Uzbekistan has been cooperating with NATO since 1994 under the Partnership for Peace. To further develop cooperation, the country will exchange experience in strengthening international relations, peace and stability, prevention of any threats to security, international terrorism, religious extremism, drug trafficking, transnational organized crime and nonproliferation of weapons of mass destruction. is being done. At the next summit of the NATO Euro-Atlantic Cooperation Council on April 3-4, 2008 in Bucharest, Uzbekistan put forward an initiative to transform the $6+2$ contact group into a $6+3$ group. 
It is known that in the East, the dream of a just king, a prosperous country has existed since ancient times. Naturally, our scholars have written various pamphlets, manuals, advice and books on this subject. As noted in the "Statutes of Temur", Amir Temur paid great attention to the council and advice in governing the state. In his works, Alisher Navoi emphasized that the king, first of all, should be distinguished by his humility, wisdom, determination, honesty, humanity, humanity, generosity, kindness to citizens, honesty, patriotism. "A just king," says the poet, "is a mirror, and it is the opposite. It is a bright morning, it is his dark night. "[11]

It should be noted that in the new conditions of Uzbekistan, "national uplift" is an attempt to develop our country, raise the political and legal thinking, living standards and quality of life of our people. The initiatives put forward by our country to take a worthy place in the world community, to establish mutual cooperation, to achieve sustainable development deserve great recognition [16-18].

Today, the reforms being carried out in our country to ensure human rights and freedoms, the administration of justice are recognized and supported by the United Nations and other international organizations. After listening to the speech of President Shavkat Mirziyoyev at the 72nd session of the UN General Assembly on September 19, 2017 [8], the heads of state and the world community assessed the changes in the protection of human rights in Uzbekistan. It is no coincidence that during the 72nd session of the UN General Assembly, the head of our state initiated the holding of the Asian Forum on Human Rights in Samarkand on the occasion of the 70th anniversary of the Universal Declaration of Human Rights in 2018.
It is noteworthy that the Samarkand Declaration on the Protection of Human Rights was adopted at the Asian Forum for Human Rights, the first in the Asian region in 70 years since the founding of the United Nations [12$15]$.

For the first time in the UN, the resolution "Strengthening regional and international cooperation to ensure peace, stability and sustainable development in the Central Asian region" [1] was adopted on the initiative of the head of our state. For the first time, the priorities of Central Asian cooperation have been identified in an international document, uniting them into a common and unified consensus. At the same time, the adoption of the resolution confirmed that the Central Asian countries are ready to take full responsibility for the fate of the region. For the first time, the goals and interests of the Central Asian states emerged as a single region. On December 12, 2018, the plenary session of the UN General Assembly adopted a special resolution entitled "Enlightenment and Religious Tolerance" [2].

The draft document was developed by Uzbekistan and unanimously supported by all UN member states. It should be noted that the adoption of this historic resolution was a practical manifestation of the initiative put forward by President Shavkat Mirziyoyev at the 72nd session of the UN General Assembly in September 2017 in New York. It should be noted that in his speech at the session, President Mirziyoyev said: "I would like to draw your attention once again to one of the most acute environmental problems of today - the Aral Sea disaster. Here is a map of the Aral Sea tragedy in my hands. I don't think there is any need to comment on that". The structure of the Trust Fund was of great importance for the 
Aral Sea region. In his speech at the 75th session of the UN General Assembly, the President also drew attention to global climate change and the Aral Sea problem. In his speech, the head of our state said: "We propose to adopt a special resolution of the United Nations General Assembly declaring the Aral Sea region a zone of ecological innovation and technology.

It would be appropriate to celebrate the date of approval of this important document as the International Day for the Protection and Restoration of Ecological Systems". On May 18, 2021, the UN adopted a "Special Resolution on the Declaration of the Aral Sea Region as a Zone of Environmental Innovation and Technology" [3].

This historical document has become a relevant document not only for Uzbekistan but also for the fate of our neighbouring countries in the Aral Sea region. This document has identified the involvement of science-based environmental innovative technologies in the development of an inclusive economy, ensuring biodiversity, protecting public health and achieving related goals, drawing the attention of the entire world community in the first place. Several relevant plans and roadmaps for the implementation of the tasks set out in this Resolution will be developed not only in our country but also in cooperation with partner countries.

On July 15-16, 2021, our country will hold a highlevel conference "Central and South Asia: regional connectivity. Threats and Opportunities " international conference. This conference reflected the common interests of all states in Central and South Asia. The participating countries agreed to carry out joint efforts against transnational threats to peace and stability. As the President said in his speech, "We have a task to turn Central and South Asia, and the whole Eurasian region in general, into a stable, economically developed and prosperous region" [10].

\section{RESULTS AND CONCLUSION}

The head of our state put forward the initiative to hold a Summit of Central Asian Leaders in 2017 to achieve the main goal of transforming Central Asia into a stable, economically developed and highly developed region, to fully realize the region's potential, strengthen mutual trust, good neighbourliness and cooperation. This vital initiative was widely supported and implemented quickly because it was in the interests of our fraternal peoples. The first summit was held in March 2018 in the capital of Kazakhstan, Nur-Sultan, the second in November 2019 in Tashkent, and the third in Avaza, Turkmenistan. At the meeting, the head of our state Sh. Mirziyoyev made several proposals on topical issues:

- Encouraging direct contacts between entrepreneurs and regions of our countries, holding regular investment and economic forums;

- Adoption of an agreement on general areas of trade and economic cooperation;

- Effective use of the transport and transit potential of Central Asia, full restoration of transport in compliance with sanitary requirements;

- Continuation of efforts to form a common energy space, including the rapid introduction of "green" energy and energy-saving technologies; Activation of the Central Asian Electricity Coordination Council, expansion of its mandate and 
powers, and increasing the level of representation of countries in the Council;

- holding regular meetings of ministers of agriculture of the region, the introduction of a regional system for monitoring food security on the agenda of the first meeting;

- Launch of a single information system for coordination and mutual assistance in combating pandemics, recognition of test results and vaccination certificates, expansion of exchange of experience in the field of prevention, diagnosis and treatment of infectious diseases, training of medical personnel, development of scientific cooperation in pharmacology and vital drugs. establishment of cooperation in production;

- Expanding cooperation in the field of environmental security, taking all necessary measures to mitigate the consequences of the Aral Sea disaster; Development of a regional program "Green Agenda for Central Asia", which will serve the adaptation of our countries to climate change, the wider introduction of resource-saving technologies;

- Noting the importance of strengthening ties between our region and other major regions of the world, he thanked the heads of state for their support and active participation of delegations in the International Conference on Central and South Asia in Tashkent. the adoption of a special resolution of the UN General Assembly on the participation of the UN Regional Center for Preventive Diplomacy for Central Asia in this process;

- Educating young people, who are a decisive force in the future of Central Asia, in the spirit of patriotism, respect for national and universal values; holding the
Central Asian Youth Forum in Uzbekistan next year;

- Holding festivals, days of culture and cinema dedicated to the cultural heritage of Central Asia, a joint publication of books;

- Active use of additional incentives to increase the exchange of tourists within the region; practical implementation of the joint program "One trip - the whole region", covering the entire range of tourism services;

- Sustaining the process of regional cooperation, to this end, the wider use of the potential of "people's diplomacy", parliaments, civil society institutions and the media;

- Holding a Regional Parliamentary Forum in Tashkent.

- Uzbekistan's prestige in the international arena is growing. This is determined, on the one hand, by the fact that Uzbekistan is one of the cradles of world civilization, on the other hand, by its commitment to ancestral traditions, ie its active role in ensuring peace and stability between peoples, states, nations and religions. All this is a blessing of independence.

\section{REFERENCES}

1. Resolution "Strengthening regional and international cooperation to ensure peace, stability and sustainable development in the Central Asian region". UN, 22 June 2018.

2. Special resolution "Enlightenment and religious tolerance". UN, 12 December 2018.

3. "Special Resolution on the Declaration of the Aral Sea Region as a Zone of 


Environmental Innovation and
Technology." UN, 18 May 2021.
4. Constitution of the Republic of
Uzbekistan. Tashkent. 2018.
5aw "On the Foundations of State
Independence of the Republic of
Uzbekistan". August 31, 1991. Lex.uz.
Law of December 26, 1996, On the
basic principles of the foreign policy of
the Republic of Uzbekistan. Bulletin of
the Oliy Majlis of the Republic of
Uzbekistan, 1997, №2.
Speech by the First President of the
Republic of Uzbekistan Islam Karimov
at the 48th Session of the UN General
Assembly September 28, 1993.

8. Speech by the First President of the Republic of Uzbekistan Islam Karimov at the 48th Session of the UN General Assembly September 28, 1993.

9. Speech by President of the Republic of Uzbekistan Sh. Mirziyoyev at the 75th session of the UN General Assembly

10. "Central and South Asia: Regional Connectivity. Speech by President of the Republic of Uzbekistan Sh. Mirziyoyev at the international conference "Threats and opportunities". July 15-16, 2021.

11. Alisher Navoi. Mahbub ul-qulub. Works. Volume 13. Tashkent: Ghafur Ghulam Publishing House of Fiction, 1966. $185 \mathrm{p}$.

12. Huseynova A. Civil Society and Women: A Monograph. - Bukhara: Bukhara Publishing House, 2009. - $142 \mathrm{p}$.

13. Khuseinova, A.A. (2010). Human trafficking: an attempt to counteract. Sociological Research, (11), 150-151.

14. Kholova, E. Kh., \& Khuseynova, A. A. (2012). The law of the Republic of
Uzbekistan "On combating human trafficking". Modern scientific research, (12), 1-1.

15. 15. Kholova, E. Kh., \& Khuseynova, A. A. (2010). Law of the Republic of Uzbekistan "on combating human trafficking". Journal of Siberian Medical Sciences, (4).

16. Kenzhaeva, Kh.P., Tozhiev, F.I., \& Zhuraev, B.N. (2014). The role of women in the creation and development of a democratic society in Uzbekistan. Innovation in Technology and Education, pp. 119-123.

17. Kenjaeva, X. P. (2021). The role of civic institutions in increasing women's social participation. Scientific progress, 1 (6), 957-961.

18. Kenjaeva, X. (2021). Educational issues in our national spiritual heritage. Society and Innovation, 2 (6/S), 18-24.

19. Djuraeva, D. D., \& Berdiyeva, Z. M. (2016). Cultural heritage as a factor of human development (on the example of Uzbekistan). Ученый XXI века, 23. 